\title{
Optimization of Waqf Land for The Construction of Hospitals Through Build Operate And Transfer
}

\author{
${ }^{1}$ TRINI HANDAYANI, ${ }^{2}$ ANITA KAMILAH \\ 1,2Universitas Suryakancana, JIn. Pasir Gede Raya, Cianjur, Indonesia \\ email: ${ }^{1}$ trinihandayani@unsur.ac.id; ${ }^{2}$ anita.kamilah@yahoo.co.id
}

\begin{abstract}
The Waqf (endowment) paradigm which is understood only for religious purposes results in a lot of unproductive waqf lands. The aim of this article is to analyze the use of waqf land for the construction of hospitals through the Build, Operate and Transfer (BOT) model in order to increase the Human Development Index in Indonesia. The research method in this article is qualitative which belongs to the category of library research with the research approach of descriptive analytic. The results of this research state that waqf positivation through Law No. 41 of 2004, which requires Nadzir (management of waqf) to manage and develop waqf property in accordance with its purpose, function and designation, becoming one of the cornerstones of the utilization of waqf land for health service business activities by building hospitals. Build Operate and Transfer (BOT) can be used as a model for utilizing waqf land in hospital business activities that play a role in entrusting waqf institutions facing limited financial resources as well as providing strategic land for investors.
\end{abstract}

Keyword: waqf land, hospital construction, bot.

\section{Introduction}

The Preamble of the 1945 Constitution mandates the state administrators to protect the entire Indonesian nation and land and to improve public welfare. This shows that the Indonesian state aside from being a legal state (rechtsstaat) as stipulated in Article 1 paragraph (3) of the 1945 Constitution at the third amendment, is also based on the welfare state. With regard to the welfare state, Bagir Manan (Manan, 1996) says that the state or government is not merely a guardian of security or public order, but bears the primary responsibility for realizing social justice, public welfare, and the greatest prosperity of the people in order to achieve the country's goals through national development.

In order to realize these national goals, economic development is needed, one of which is through the development of religious institutions potential that do not only provide religious and social facilities but also have economic benefits, namely "Wakaf" or Waqf institutions.

In the provisions of Indonesian national law, provisions regarding waqf are included in Law Number 5 of 1960 concerning Basic Agrarian Principles, Article 49 Chapter XI concerning Land Rights for Sacred and Social Purposes, and Law Number 412004 concerning Waqf which is further regulated in Government Regulation Number 42 of 2006 (Mubarok, 2013).

Referring to the contents of the laws and regulations, there is a similar function of waqf which is to realize the potential and economic benefits of waqf property for the purposes of worship and to promote public welfare. The function of waqf emphasizes on the interests of worship, social, and public interests; then when the use of waqf objects, especially land for purposes other than economic activities in the broadest sense, namely for hospital construction still raises pros and cons because it considers having deviated from the original purpose and function of the waqf. On the other side, there are many people need health development facilities but have difficulties due to the limited availability of land. In order to examine the issue more deeply, the research questions are (1) Is it justified to use waqf

Received: 2019-07-02, Revised: 2019-08-29, Accepted: 2019-12-23

Print ISSN: 0215-8175; Online ISSN: 2303-2499. DOI: https://doi.org/10.29313/mimbar.v35i2.4850

Accredited Sinta 2 based on the decree No.10/E/KPT/2019 until 2024. Indexed by DOAJ, Sinta, Garuda, Crossreff, Dimensions 
land for the establishment of hospitals in order to increase the Human Development Index in Indonesia; and (2) How is the use of waqf land for the construction of hospitals through the Build Operate and Transfer (BOT) model.

\section{Research Methodology}

This research is qualitative research in accordance with the object of study. In this article, this type of research falls into the category of library research. According to Kaelan, in library research, sometimes it has descriptive and also historical traits including those in religious research. Therefore, library research will face data sources in the form of large numbers of books y so that they require adequate methods. For this reason, collecting books must be done gradually or there will be difficulties if not. Data used is obtained from various references both primary and secondary. These data are collected by documentation techniques, namely by reading, studying, and recording the literature that has to do with the problems discussed in this article.

The technique used in this article is the data analysis technique modeled by Miles and Huberman. In this model, qualitative analysis activities are carried out interactively and continuously until they feel sufficient. According to Kaelan, there are two stages in data analysis techniques in this library research. First, the analysis at the time of data collection is intended to better capture the essence or core of the research focus; this process is carried out aspect by aspect in accordance with the research map. Second, after the data collection process has been carried out, and then it is analyzed again after the data collected in the form of raw data that must be determined by relations with each other. The collected data may not necessarily answer all the problems raised in the study, therefore, it is necessary to re-analyze the data that has been clarified. Data analysis activities of this model include data reduction, display of data, and description of conclusions or verification (Nasution, 2008).

\section{Results and Discussion}

\section{The Relevance of Waqf with Build Operate Transfer System}

The regulation of land in Indonesia is regulated in Law Number 5 of 1960 concerning Agrarian Principles (Undang-Undang Pokok Agraria / UUPA) as the legal basis of land law and all matters relating to land and is followed up by various other laws and regulations. In the preamble of the UUPA, it is stated: "In connection with the above considerations, there is a need for a National Agrarian Law, which is based on customary law on land that is simple and guarantees legal certainty for all Indonesian people without ignoring the elements that rely on religious law". Matters relating to land that rely on religious law as referred to in the considerations of the UUPA are regarding land representation (Hamami, 2003)

Waqf in Indonesia continues to grow as evidenced by many historic mosques built on the historic land of waqf land. This happens because the position of waqf as a form of worship is expected to be a saving for those who have donated their wealth (wakif) as their provisions in the hereafter. In a hadith narrated by Bukhari Muslim, "When Adam's son (a man) dies, then all his deeds come to an end (because he is dead) except for three things (which keep generating even though he is gone), namely Shadaqoh Jariah or ceaseless charity (including waqf), beneficial knowledge, and pious/virtuous children who always pray for him". Legal provisions regarding waqf in Indonesia have been specifically regulated in Act Number 41 of 2004 concerning Waqf (Waqf Law). According to Article 1 number (1) of the Waqf Law, Waqf is "The legal act of endowment to separate or surrender a part of his assets forever or for a certain period in accordance with his interests for the purposes of worship or general welfare according to Sharia" (Huda, 2015).

According to the Waqf Law article 16, it is explained that land (immovable objects) that can be represented includes a) land rights in accordance with applicable laws and regulations, either those that have been registered and those that have not been yet; $b$ ) buildings or parts of buildings that stand on the ground; c) plants and other objects related to the land; d) ownership rights to the apartment units in accordance with the provisions of the applicable laws and regulations; e) other immovable objects in accordance with the provisions of Sharia and the applicable laws and regulations. Furthermore, letters $b, c$, and d in paragraph (1), article 17 of Government Regulation Number 42 of 2006 concerning the Implementation of Law Number 41 of 2004 concerning Waqf (Peraturan Pemerintah tentang Waqaf/PP Waqf) affirmed that the Hak Guna Bangunan/HGB (Right to Build), Hak Guna Usaha/HGU (Cultivation Rights), Hak Pakai/HP (Right to Use) above State land, 
as well as HGB or HP above management rights or Hak Pengelolaan/HPL (Right to Manage) or Ownership Rights (Hak Milik/HM) and Hak Milik atas Satuan Rumah Susun/ HM-SRS (ownership rights to the unit of flats) can be endowments. The preamble of Law No. 41 of 2004 concerning endowments also explain strategic steps to improve public welfare: it is necessary to increase the role of waqfs as religious institutions that do not only aim to provide various types of worship and social facilities but also become a potential economics force which in the end can be directed towards the progress of public welfare; it is deemed necessary to do or create a floating system and the use of waqf land which has to be still in accordance with Islamic principles as the basis of the concept (Rozalinda, 2015).

Simply put, waqf can be used for commercial or non-profit purposes. Generally, waqf is understood as an infrastructure provider for religious nonprofit activities, such as the construction of mosques, madrasah (schools), and cemeteries. In reality, waqf can be managed as an investment that is commercial in nature. Distribution of waqf for the non-profit sector will play a role in the operational of non-profit sector. For example, waqf land was used to build a special hospital for poor people; this waqf will be useful in the operation of health services in the hospital. In general, waqf land in Indonesia is used to build mosques, mushalla (small mosques), schools, cemeteries, orphanages, or pesantren (Islamic boarding schools). The use in terms of socio-religious aspects, especially for religious purposes, is indeed effective, but the benefits are less influential, especially for the economic life of the community.

If the designation of waqf is limited to the above, without more productive management of the waqf, then the social and economic welfare of the community as expected by waqf institutions in Indonesia cannot be realized quickly and optimally. The majority of Indonesia's population is Muslim living in an area equivalent to the European landscape which can be a great potential for waqf. Until now, the waqf of land in Indonesia that has been successfully recorded is not less than 400 thousand parcels of land with an area of more than 4 billion square meters. It is a real waqf asset, no longer a picture of potential. However, most of the waqf assets are used for madrassas, mosques, and cemeteries which have limited economic benefits.
Based on data from Badan Waqaf Indonesia/BWI (Indonesian Waqf Board), the assets of waqf land spread across 33 regions throughout Indonesia are very large, reaching 4,142,464,287,906 $\mathrm{M}^{2}$ (Direktorat Pemberdayaan Wakaf /Directorate of Waqf Empowerment, 2015). However, this potential has not been managed by a more productive concept. Most of the waqf was used to build mushalla, mosques, and cemeteries. Very few are allocated to the productive sector that provides economic benefits to the community. In fact, almost all waqf is surrendered to Nazhir without funds to finance the operations of productive businesses of waqf. This would certainly be a problem and a serious obstacle in managing the waqf. Therefore, a real strategy is needed for the management of waqf assets to handle a quite numerous waqf land that spread throughout the regions in Indonesia. The sooner they get empowered, the sooner the community gets the benefit of improving the overall welfare (Hasan, 2008).

Indeed the Waqf Law Article 43 paragraph (2) has mandated the management of productive waqf. The productive waqf management can be carried out by building commercial hospitals, mining, apartment development, sharia hotels, shophouses, sports fields, office buildings, and others, which use orientation or the results are still allocated for the benefit or development of Muslims as an objective initially. Waqf land with a large land area and is in a strategic location has the potential to be developed and managed more productively. As is the case today, many waqf lands are used to build mosques or prayer rooms, while the remaining large land has the potential to increase the productivity of waqf land by, for example, constructing commercial buildings such as shophouses or meetinghouses for rent. The rent income received can then be used to maintain the mosque, to take care of the existing waqf building, to sustain the activities or to empower people who have small or poor economic businesses (Mubarok, 2008).

The concept of waqf land use is actually and commonly practiced in various countries such as Singapore, Malaysia, Saudi Arabia, and Egypt. Several other countries in the Middle East apply the concept of using waqf land as productive land by involving the capital owners who make mutually beneficial business agreements. One form of the agreement in question can be done with the Build, Operate and Transfer (BOT) agreement 
system.

Typically, the BOT agreement is one of the concepts of a cooperation agreement implemented between the holders of rights over objects or in this case the government, private, or individual land with investors stating that the holder of the land rights (the owner) gives the investor the right to carry out development during the period stipulated in the BOT agreement and all the economic benefits as well as transferring ownership of the building to the holders of land rights after the term of the building (BOT) for delivery ends (Santoso, 2008). In the agreement of BOT system, the owner of exclusive rights (government) or the strategic landowner (community or private) delegates the construction of the project to the capital owner (investor) to finance the construction within a certain period, then the capital owner is given the authority to manage the building in question (concession rights) in order to take economic benefits (or by a percentage sharing profit model) (Kamilah, 2012). After the agreement period is over, the management of the building concerned is returned fully to the landowner. Implementing the BOT agreements in waqf land should pay close attention to the limitations of rights attached to waqf land as it stated in the Waqf Law Article 40 that waqf assets that have been represented are prohibited from being used as collateral, confiscated, granted, sold, inherited, exchanged, or transferred in the form of other transfer of rights.

The application of the BOT system for the construction of commercial buildings (hospitals) on waqf land in Indonesia is still rare. Apart from the lack of understanding of the community, especially nazhir, it is caused by the limitations of certain rights of waqf land. The application of BOT system in the construction of commercial buildings on waqf land lacks the interest of investors because of certain considerations, one of which is likely the constraints that are conventionally (collateral in the form of land) required by banks so that funds from the banks will not be given without the presence of adequate guarantees. Besides land ownership rights, land use rights, building rights (HGB), the use of rights, and management rights can also be represented.

This is in accordance with Government Regulation Number 42 of 2006 concerning the Implementation of Endowment/Waqf Regulations, stating that HGB can be represented either forever or for a while. HGBs that are temporarily represented and managed by Nazhir through the BOT agreement can cause legal problems, especially regarding the status of the agreement and legal protection of investors. It particularly occurs when the waqf of HGB ends earlier than the BOT agreement. Therefore, there must be harmony between the HGB and the drafting of the agreement.

\section{Utilization of Waqf Land for Hospital Construction}

Waqf is a social instrument in Islam that plays an important role in improving people's welfare by increasing the income of the poor, which is managed by individuals and legal entities (Asytuti, 2012).

Endowments/waqf terminology that has been adopted into the Indonesian language is derived from Arabic. It is a masdar form or an inverse word of a verb or fi'il: waqafa. This waqafa verb sometimes requires an object (muta'addi) and sometimes does not require an object (common). Synonyms of waqf are abs, waqafa, and abasa in the form of verbs which mean stopping and holding or stopping in place (Furqon, 2012). Whereas, according to the Law on Endowments Number 41 of 2004 "Waqf is a legal act of wakif to separate part of his property to be used forever or within a certain period of time according to his interests for the purposes of worship or general welfare according to Sharia" (Muntago, 2015).

The Shorter Encyclopedia of Islam refers to the notion of waqf according to the term Islamic law, which is to protect it from being a property of a third person. It means to maintain something or object by holding it so that it does not become the property of a third party. The object held must be an object that remains in its substance, released by one who has his own power in certain ways and conditions, but the results are picked and used for the purposes of virtues determined by Islamic teachings.

Terminologically in Islamic law, according to the definition that is most widely followed, waqf is defined as "institutionalizing an object that can be taken advantage of by stopping the right of the act of the waqf actors or other to the object and channeling the results to the existing channels or for social purposes kind". There is also a definition of waqf as "holding an object not transferred forever and donating benefits (results) to poor 
people or for good purposes" (Anwar, 2007).

The waqf paradigm in Indonesia is less supportive of optimizing waqf empowerment. It only provides an understanding of waqf solely for religious purposes, such as places of worship, as well as social interests only (Damanuri, 2012). This waqf tradition rises various phenomena that resulted in the representation of Indonesian that does not experience encouraging developments for the benefit of many people. In terms of the types of objects, the endowments carried out by Indonesian people are mostly in the form of land built for the purposes of mosques, mushallas, madrassas, and cemeteries. There is also paddy fields and plantations, but since the limited ability and narrow understanding of waqf itself resulting in a lot of unproductive waqf land (Mubarok, 2013).

Based on data from the Directorate of Waqf Empowerment, the Ministry of Religion of the Republic of Indonesia, until March 2016 , the total area of waqf land throughout Indonesia reached $4,359,443,170.00 \mathrm{M}^{2}$, of which 287,160 were certified, while 148,447 were not certified yet. The number of waqf assets in Indonesia is the largest in the world (Piliyanti, 2010) and it is a potential asset to overcome economic, social, and educational problems if it managed productively and professionally (Furqon, 2012). However, from the vast amount of land represented, its utilization is not optimal because it is only limited to religious and social activities. There is still a lot of abandoned land that does not provide benefits for the welfare of the people and becomes a burden to the Nadzir.

The promulgation of the law is the first step for a new era of representatives in Indonesia because the arrangement is more comprehensive, for example, the scope of objects that can be represented which generally understood to be limited to waqf of immovable objects of land and buildings, is now becoming more diverse in the form of money, precious metals, securities, vehicles, intellectual property rights, rental rights, and other movable objects including the use of waqf objects themselves (Muslim, 2015).

Positivisation of waqf through the provisions of Article 42 Chapter $V$ of Law No. 41 of 2004, which requires Nadzir to manage and develop waqf property in accordance with its objectives, functions, and designation becoming one of the cornerstones in answering pros and cons relating to the utilization of waqf land for business activities, as well as other social interests such as the construction of hospitals (Lubis, 2015).

Hidayat (2016) gave his view that waqf is basically an "economic corporation" which contains elements of investment as the main foundation for the development of a productive economy that is able to generate profits and can be used for the welfare of the people as mandated by wakif in the waqf pledge.

Elaborating the views of Mubarok (2008) and Qahaf (2006), productive waqf means the management of waqf professionally to increase the utilization of waqf, either in agriculture, industry, trade and other fields, one of which is the construction of a hospital to provide health services in improving the Indonesian Human Development Index, which is in accordance with the purpose of waqf. Several countries and institutions have implemented productive endowments through business activities. For example, the Islamic Development Bank (IDB) which formed the World Waqf Agency in 2001 by developing representatives in the real sector and trading shares. Investments are made in several countries such as Qatar, Kuwait, Malaysia and several other countries in the form of hotels, offices, and agriculture. The Kuwait Public Waqf Foundation (al amanah al 'aamah li al-awqaf) places the representative as an economic instrument and social security. Turkey has developed health services through hospital waqf, one of which is a hospital founded in 1843 in Istanbul by the mother of Sultan Abdul Mecit who became known as Bezmi Alan Valid Sultan Guraki Muslim. The hospital is currently one of the modern hospitals which have 1,425 beds and approximately 400 doctors, nurses, and staff (Hasan, 2008).

The application of productive waqf is in line with the principles contained in the provisions of Law No. 41 of 2004 which empower the waqf assets to realize the potential and economic benefits of waqf property so that they can improve people's welfare.

The Human Development Index (HDI) is an indicator of the level of welfare of a country. Indonesia is ranked 87th out of 157 countries. Components that influence the HDI are the Education Index, the Health Index, and the Purchasing Power Index. One strategy to improve HDI in the health sector is to establish a hospital, considering the number of hospitals in Indonesia is still lacking 
according to the standards of the World Health Organization (WHO), namely 1 bed (TT) of patients in hospitals is comparable to 1,000 residents.

The following are data on the number of beds per 100,000 population and the number of hospitals based on the region in 2018:

Based on table 1 , if it is according to the indicators from the Ministry of Health, only Region 1 areas that still need hospitals since out of 889 beds in 1,402 hospitals there are still a shortage of 636 beds. When it is compared to WHO standards, all regions still experience a shortage of hospital beds. Hospital development is prioritized for Region 1 , meanwhile, based on regional analysis, Region 4 and Region 5 need to be prioritized according to territorial profiling. Investing in the hospital requires a long time to Break Event Point (BEP). On average, the BEP will be achieved in the 10th year onwards.

\section{Utilization of Waqf Land for Hospital Development through Build Operate and Transfer (BOT)}

The Build Operate and Transfer (BOT) concept began to become widely known around 1985 in Turkey when the Prime Minister Turgut Ozal introduced the concept of privatization known as "Turgut's Formula" for the construction and management of dams on the Syehan river with a project value of 231.5 million US dollars (Kamilah, 2012). The concept of BOT is widely adopted by developing countries including Indonesia in the construction of infrastructure projects in the midst of limited government funding in the State Expenditure Budget (APBN) and the Regional Expenditure Revenue Budget (Anggaran Pendapatan Belanja Daerah/ APBD).

In the provisions of Indonesian national law, there are no comprehensive rules regarding BOT cooperation. The foundation on which the BOT agreement is based is only the principle of freedom of contract stipulated in Book III of the Civil Code concerning Engagement (Van Verbintenissen) Article 1338 paragraph (1) of the Civil Code which states that everyone has the freedom to make any agreement on anything, including the construction of hospitals originating from the use of waqf land through the BOT model with provisions that are not violating the law, public interest, and decency (Murdiana, 2015).

However, understanding the concept of BOT can be based on the Decree of the Minister of Finance of the Republic of Indonesia No. 470/KMK.01/1994 concerning Procedures for the Elimination and Utilization of Property or State Wealth. It states that Build Operate and Transfer (BOT) agreement is the utilization of goods or property of state assets in the form of land by other parties, by the way, the other party constructs buildings or other facilities on the land and utilize them within a certain period of time, then return the land, buildings, or other facilities along with their utilization to the relevant department or institution after the end of the agreed period (Jamilah, 2012).

Referring to these provisions, in order to optimize waqf land in the midst of financial

Table 1

Hospital by Region

\begin{tabular}{cccccc}
\hline Region & $\begin{array}{c}\text { Number of } \\
\text { hospitals }\end{array}$ & $\begin{array}{c}\text { Number of } \\
\text { bed }\end{array}$ & Total Population & $\begin{array}{c}\text { Bed } \\
\text { Target }\end{array}$ & $\begin{array}{c}\text { WHO } \\
\text { Target }\end{array}$ \\
\hline Region 1 & 1.402 & 889 & 152.449 .900 & 1.525 & 152.500 \\
Region 2 & 413 & 735 & 39.183 .700 & 392 & 39.200 \\
Region 3 & 702 & 2.068 & 51.935 .100 & 519 & 51.900 \\
Region 4 & 134 & 622 & 11.634 .900 & 116 & 11.600 \\
Region 5 & 159 & 700 & 13.069 .300 & 131 & 13.100 \\
\hline
\end{tabular}

Source: https: //sirs.yankes. kemkes.go.id/fo and processed Central Statistics Agency, 2018 Note:

In table 1, Region 1 is a joint territory of the Special Province of the Capital City, West Java, Central Java, Special Region of Yogyakarta, East Java and Banten;

Region 2 consists of West Sumatra Province, Riau, South Sumatra, Lampung, Bali, and West Nusa Tenggara;

Region 3 consists of Nanggroe Aceh Darussalam Province, North Sumatra, Jambi, Bengkulu, Bangka Belitung Islands, Riau Islands, West Kalimantan, North Sulawesi, Central Sulawesi, South Sulawesi, Gorontalo and West Sulawesi; Region 4 consists of Central Kalimantan Province, South Kalimantan, East Kalimantan;

Region 5 consists of East Nusa Tenggara, Maluku, North Maluku, West Papua and Papua Provinces. 
constraints experienced by waqf institutions, a solution can be applied is the use of Build Operate and Transfer (BOT) model. Through the BOT model, Nazhir as the party that receives the waqf property can partner with a third party (investor) to fund the construction of hotels, trade centers, offices, and hospitals on waqf land. The investor is given the right to construct for a certain period of time as agreed between Nadzir and the investor, and then after the BOT period is completed, the investor is obliged to surrender the land, hospital building, and/or supporting facilities back to Nadzir.

Optimizing waqf land for the construction of hospitals through the BOT model gives benefits for Nazhir and investors. Benefits for waqf institutions: a) Waqf land optimization is funded by investors so that it can reduce the number of loan funds from third parties, as well as provide solutions for waqf institutions in facing constraints of limited funds; b) Financing the construction of a hospital with a BOT system will benefit both financially and administratively because the waqf institution does not have to conduct a feasibility study. The project will be financed and carried out by and at the risk of the investor based on the quality of the results of hospital development; c) During the operation (management) of the hospital, the waqf institution will get rent or royalty for the amount stated in the agreement; d) At the end of the management period, the hospital building and all supporting health service facilities are left to the waqf institution; and in order to keep the hospital building and supporting facilities in good condition, the waqf institution can oblige the investor to carry out maintenance and repairments of the hospital building during the BOT period; f) Optimizing waqf land through hospital development activities can open up employment opportunities and reduce the number of unemployment; g) Financing the construction of hospitals through the BOT system does not burden the waqf institution since they do not have to borrow funds (Wirana, 1994).

Benefits for investors: (a) Investors can take advantage of the strategic land owned by waqf institutions for hospital development in the midst of limited land; (b) Expanding business to other fields that have good prospects and are profitable; (c) Creating a new business field and climate.

Thus, the use of waqf assets for the construction of hospitals through BOT provides benefits for both parties of waqf institutions as parties given mandate by Wakif as well as for investors as parties who have funds. Benefit for private sector is that their investors can build a hospital to provide health services without having to own land. Waqf institutions only have strategic land and when they want to use that land they need to have funds to cover the high cost of the project. By using the BOT model, in the short term, waqf institutions will get funds for financing the project development and also receive compensation or royalties from managing the project. In the long term, after the BOT period ends, the waqf institution will get the building, facilities, and infrastructure, so that the BOT agreement will not only save waqf institution funds, but also increase financial receipts during the construction, operation, and at the time of handing over the hospital building. The utilization of waqf land for hospital construction through this BOT model does not only provide benefits for waqf institutions and investors but also for the wider community who need health services. It means shifting the paradigm from 'private benefits' to 'social benefits' (Darwanto, 2012) which fulfilled the function and purpose of waqf as mandated in Article 4 and Article 5 of Law Number 42 of 2004 in promoting the welfare of the people. Thus, creating a triangle synergy between waqf institutions, business or social, and communities are strengthening state policies as stipulated in Law Number 42 of 2004 concerning waqf which provides a place to increase the function and role of waqf productively. The private sector (investors) encourages the creation of jobs and increased income for the community and the community accommodates social and political interactions and participates in these social and politicaleconomic activities (Susantono and Berawi, 2012).

Utilization of waqf land in hospital development activities is not intended to equalize waqf management with business management in the private sector, but in accordance with Chapter V Article 42 and Article 43 of the Law on Waqf management and development of waqf assets carried out with Sharia principles namely a rule agreements based on Islamic Law between waqf institutions and investors and those who relevant to the use of waqf land through BOT (Supriyadi, 2003), such as banks, contractors, insurance companies, and tenants. It is all based on the following principles: : (1) Inter-Chinese principles (voluntary in 
contract). (2) Principles of al-I'timad 'ala la-nafs (entrepreneurship). (3) al-ta'awun principle (mutual benefit in useful matters ) (4) principle of al-mas'uliyah (responsibility). (5) The principle of al-tasyir (ease) because all of the activities are permissible as long as there are no restrictions. (6) al-idariyah principle (correct and transparent financial administration), (7) principle of al-takaful al-ijtima'i (social responsibility), and (8) alikhtiyat principle (caution) (Ismanto, 2014).

In the empirical level, the use of waqf land in hospital development activities through the BOT model in addition to having benefits is also inseparable from the risk, namely the potential loss due to unexpected events which can cause adverse effects (Karsaman et al., 2015), among them, are a) Legal Risk, namely the possibility of unenforceable or inoperability of contracts either in whole or in part made by the parties; b) Economic Risk, namely the calculation of the project based on incorrect assumptions and bias towards project implementation costs, market conditions, or sudden currency movements so that the situation is very difficult for investors to continue implementing the BOT agreement (Yasa, Dharma, and Sudipta, 2013); c) Force majeure or overmacht, for example, the occurrence of unexpected conditions for BOT objects, such as fire, natural disasters, war, riots that are directly related to or affect the implementation of the BOT agreement so that the BOT agreement is impossible to continue; d) Market and Income Factors, namely loss of income caused by insufficient direct income from the project and lack of income from other sources related to the project (Kamilah, 2012).

Considering the impact of these risks can hinder the purpose of utilizing productive waqf land in the development of the hospital, it is necessary to carry out risk mitigation which is carried out by both waqf institutions and companies in decision making (Waryhas, 2015). Actions that can be taken in dealing with risks are 1) Risk Retention is carried out through certain actions because the impact of an adverse event is still acceptable; 2) Risk Reduction, by conducting in-depth study of these risks and making prevention efforts on risk sources or combining efforts so that the risks received do not occur simultaneously; 3) Risk Transfer, which is carried out by ensuring the risk of either partially or wholly to other parties who will provide guarantees or dependents if these risks actually occur in the BOT agreement: 4. Risk Avoidance is done by avoiding activities with a high level of loss (Yasa, Dharma, and Sudipta, 2013).

\section{Conclusions}

The land is one of the waqf objects managed by wakif through the separation of parts of wakif objects to be used forever or in a certain period of time according to their interests for the purpose of worship or public welfare through waqf optimization in the construction of hospitals as the development of productive waqf. Productive waqf is the professional management of waqf to increase the benefits of waqf, one of which is through the construction of hospitals that are able to generate benefits that can be used for the welfare of the people as mandated by wakif in the waqf pledge. Utilization of waqf land for the construction of hospitals through the Build Operate and Transfer (BOT) model is a model of the utilization of waqf land in the midst of financial constraints where Nadzhir as the party that receives waqf property cooperates with third parties (investor) to fund the construction of a hospital on waqf land. Investors are given the right to operate the construction of the hospital infrastructure for a certain period of time as agreed between Nadzir and investors, and then after the BOT period is complete, the investor must submit land, buildings, hospitals and other health service supporting facilities to Nazir.

\section{Acknowledgment}

The first author would like to thank the postgraduate law and LPPM (Institute of Research and Community Service) University of Suryakancana for their input and suggestions in the making of this article. The second author would like to thank the Faculty of Law and lecturers who provided facilities and time to discuss formulating this article.

\section{References}

Anwar, S. (2007). "Studi Hukum Islam Kontemporer". Jakarta: RM. Books.

Asytuti, R. (2012). Optimalisasi Wakaf Produktif. AT - TARADHI Jurnal Studi Ekonomi, Vol. 3, No. 1, pp. 16-30.

Damanuri, A. (2012). Efektivitas Dan Efisiensi Pemanfaatan Harta Wakaf Majlis Wakaf Pimpinan Daerah Muhammadiyah Ponorogo. Jurnal Kodifikasia, Vol. 6, No. 1 , pp. 46-59.

Darwanto. (2012). Wakaf Sebagai Alternatif Pendanaan Penguatan Ekonomi Masyarakat Indonesia. Jurnal IImu Manajemen dan Akuntansi Terapan, Vol. 
3, No. 1, pp. 89-102.

Direktorat Pemberdayaan Wakaf. (2015). "Perkembangan Pengelolaan Wakaf di Indonesia". Jakarta: Departemen Agama RI.

Furqon, A. (2012). Wakaf Sebagai Solusi Permasalahan Dunia Pendidikan Di Indonesia. Jurnal At-Taqaddum, Vol. 4, No. 2, pp. 1-14.

Hamami, T. (2003). "Perwakafan Tanah (Dalam Politik Hukum Agraria Nasional)", Jakarta: Tatanusa.

Hasan, T. (2008). "Perkembangan Kebijakan Wakaf di Indonesia". Jakarta: Republika.

Hidayat, A. (2016). Wakaf Produktif (Implementasi UU No. 41 Tahun 2004 Tentang Wakaf). bil dalil (Jurnal Hukum Keluarga Islam), Vol. 1, No. 1, pp. 47-60.

Huda, M. (2015). "Mengalirkan Manfaat Wakaf, Potret Perkembangan Hukum dan Tata Kelola Wakaf di Indonesia". Bekasi: Gramata Publishing.

Ismanto, K. (2014). Penerapan Prinsip-Prinsip Syariah Pada Perjanjian Asuransi Syariah Di Ro Takaful Keluarga Pekalongan. Jurnal Hukum Islam (JHI), Vol. 12, No. 1, pp. 110-123.

Jamilah, L. (2012). Asas Kebebasan Berkontrak Dalam Perjanjian Standar Baku. Jurnal Syiar Hukum, Vol. XIII, No. 1, pp. 19-35.

Kamilah, A. (2012). "Bangun Guna Serah (Build Operate and Transfer/BOT) Membangun Tanpa Harus Memiliki Tanah (Perspektif Hukum Agraria, Hukum Perjanjian, dan Hukum Publik)". Bandung: Keni Media.

Karsaman, H., Rodhiatun, R., Al-Rasyid, H, and Santoso, I. (2015). Kajian Investasi Pembangunan Jalan Tol di Indonesia Berdasarkan Sistem Syariah: Studi Kasus Jalan Tol Cikampek-Palimanan". Jurnal Perencanaan Wilayah dan Kota, Vol. 26, No. 2, pp. 108-131.

Lubis, D., Syaddan; Lubis, Y, Barus, M., C, S.B, Rosnidar. (2015). Hubungan Hukum Pengelolaan Wakaf Antara Nazhir Dan Badan Wakaf Indonesia Provinsi Sumatera Utara Terhadap Tanah Wakaf Yang Belum Terdaftar (Studi Di Kota Medan). USU Law Journal, Vol. 3, No. 3, pp. 75-87.

Manan, B. (1996). "Politik Perundangundangan Dalam Rangka Mengantisipasi Liberalisasi Perekonomian". Lampung: Fakultas Hukum UNILA.

Mubarok. (2013). Model Pengembangan Wakaf Produktif (Studi tentang Pengelolaan Wakaf pada Yayasan Muslimin Kota Pekalongan). Jurnal Hukum Islam (JHI), Vol. 11, No. 1, pp. 18-32.

Mubarok, J. (2008). "Wakaf Produktif".
Bandung: Simbiosa Rektama Media.

Murdiana, E. (2015). Asas Kebebasan Berkontrak Dalam Perjanjian Syari'ah (Implementasi Pada Perjanjian Baku Di Baitul Maal Wa Attanwil/Bmt Kota Metro), Jurnal TAPiS Vol. 15, No. 02, pp. 66-83.

Muslim, M. (2015). Pergeseran Pemahaman Terhadap Waqaf Di Era Global Dan Implikasi Hukumnya. Istinbath, Jurnal Hukum Islam, Vol. 14, No. 2, pp. 39-43.

Muntago, F. (2015). Problematika dan Prospek Wakaf Produktif di Indonesia. Jurnal ALAHKAM, Vol. 25, Nom. 1, pp. 60-74.

Nasution. (2008). "Metode Penulisan Naturalistik Kualitatif". Bandung: Tarsito.

Piliyanti, I. (2010). Transformasi Tradisi Filantropi Islam: Studi Model Pendayagunaan Zakat, Infaq, Sadaqah Wakaf Di Indonesia. CONOMICA, Jurnal Pemikiran dan Penelitian Ekonomi Islam, Vol. II, No. 2, pp. 90-104.

Qahaf, M. (2006). "Al-Waqf al-Islami Tathawwuruh Idaratuh Tanmiyatuh". Damaskus: Dar al-Fikr.

Rozalinda. (2015). "Manajemen Wakaf Produktif". Jakarta: PT. Rajagrafindo Persada.

Santoso, B. (2008). "Aspek Hukum Pembiayaan Proyek Infrastruktur Dengan Model BOT (Build Operate Transfer)". Jakarta: Genta Press.

Susantono, B., \& Berawi, A.M. (2012). Perkembangan Kebijakan Pembiayaan Infrastruktur Transportasi Berbasis Kerjasama Pemerintah Swasta Di Indonesia. Jurnal Transportasi, Vol. 12, No. 2, pp. 26-32.

Supriyadi, A. (2003). Sistem Pembiayaan Berdasarkan Prinsip Syariah (Suatu Tinjauan Yuridis Terhadap Praktek Pembiayaan Di Perbankan Syariah Di Indonesia). Jurnal Al-Mawarid, Vol. X, No. 3, pp. 48-64.

Waryhas, M. (2015). It Looks Like a Good Deal- But Is It a Fair Deal. The Journal Publication of Stout Risius Ross, Vol. 4. No. 2, pp. 114-130.

Wirana, P.A. (1994). "Penelitian Tentang Aspek Hukum Perjanjian Build Operate and Transfer (BOT)". Jakarta: Badan Pembinaan Hukum Nasional Departemen Kehakiman RI.

Yasa, I.W., Dharma, I.G.B., Sila, G.K. (2013). Manajemen Risiko Operasional Dan Pemeliharaan Tempat Pembuangan Akhir (TPA) Regional Bangli Di Kabupaten Bangli. Jurnal Spektran, Vol. 1, No. 2, pp. 67-75. 